\title{
Bob Tollison, Adam Smith's pin factory, and the flow of knowledge: a personal memory
}

\author{
Bruce Yandle ${ }^{1,2}$
}

Received: 12 November 2016/Accepted: 31 January 2017/Published online: 27 February 2017

(C) Springer Science+Business Media New York 2017

I first met Bob Tollison at the 1969 Southern Economic Association meeting in St. Louis, MO, USA. Armed with a freshly minted University of Virginia Ph.D., Bob had just joined the Cornell economics faculty. Jim Miller, my Georgia State dissertation chairman and a Tollison close friend, introduced us. Jim and Bob, both students in James M. Buchanan's much celebrated Jefferson Center, had walked the Lawn together when their UVA doctorates were granted. Bob Tollison was laid back that day, quick to smile, casually dressed, and courteous.

When we met at the Southern, Jim quickly summarized my thesis idea, and Bob, just as quickly, offered an alternative way to approach the work. His face took on a serious look when he suggested that I tool up on Walras's notion of tatonnement. I soon learned that this was vintage Bob Tollison, always ready to engage in a discussion of economic theory with both sides of his doubled-barreled brain firing.

As I observed over the next 47 years, Tollison never seemed to be rushed, even though he regularly and systematically produced the work of 10 or more research economists. He was a study in understatement. Indeed, just Bob's work on rent seeking would be sufficient to satisfy most scholarly yearnings for significant accomplishment. But there was more to his amazing productivity than suggested in Malcolm Gladwell's Outliers (2008). Gladwell argued there are darn few individuals who are truly outliers in some profound sense that makes them different from other mortals. Instead, he argues that extraordinary performers simply work harder than everyone else. Bob did in fact work harder than most of us. But that hard work was multiplied by his double-barreled brain and an amazing memory. Working together in a powerful production function, the brain, coupled with a passion for economics, enabled him to build a working knowledge of the wide and deep main streams and flows of economic thought and to contribute mightily to those streams.

Bruce Yandle

yandle@bellsouth.net

Alumni Distinguished Professor of Economics Emeritus, Clemson University, Clemson, SC, USA

2 Distinguished Adjunct Professor of Economics, Mercatus Center at George Mason University, Arlington, VA, USA 
Bob had many gifts, as we sometimes put it. Chief among them was his amazing ability to identify powerful ideas in their embryonic stage, shape those ideas into prose, and fit the prose into the deepest and strongest stream of emerging economic thought. Whether alone or primarily with co-authors, he had the gift that enabled him to transform ideas into writing. He was imprinted by James M. Buchanan's admonition: "If you aren't writing, you are not thinking." Bob thought a lot!.

The pantheon of Bob's coauthored work, which included more than 500 individuals, was testament to how seriously he applied Adam Smith's ideas to his own life and work (Crain and Crain 2010, 265). In this case, it was Smith's famous use of a pin factory to illustrate the notions of specialization and division of labor. Bob made no bones about the matter: he believed in specialization when it came to building research-based publications or even organizing a departmental dinner. For example, he made no claim to being an econometrician, but he understood precisely when and how to pair up with econometrician colleagues to produce empirical work that shed bright new light in some dark rooms. And he knew how to evaluate econometric findings. Those dimly lit rooms that received important illumination from Bob's lamp contained questions about public choice, history of thought, sport economics, monetary policy, antitrust, religion, and a host of other topics.

Bob's high level of scholarly production was rooted in self-discipline. He never seemed to waste a minute, even in unusual circumstances. I saw an example of this in 1982 when he was serving as director of the FTC's Bureau of Economics and I was the agency's executive director. Once again, then FTC chairman Jim Miller had brought us together. Jim, deeply committed to President Ronald Reagan's reform efforts, believed in running a tight ship as he piloted the agency in politically dangerous Washington waters; he wanted his leadership team to know what was going on, to be aware of the multiple threats and opportunities that constantly surfaced both inside and outside the agency. To accomplish this, the senior staff met first thing every morning around Chairman Miller's conference table. There, as the work day began, sat all the bureau heads, chief of staff, general counsel, head of congressional relations, and director of agency media relations. Tollison never missed a meeting, and he always came with yellow pad in hand, the same sort of yellow pad that was always on his desk when working in his office. While Jim Miller briefed the staff and conducted business, Tollison, eyes cast down, would write deliberately on his pad and often have 10 pages written by the time the hour-long meeting ended.

At first, I wondered, was Bob taking scrupulous notes in an attempt to capture the essence of what was being said around the table? Was he composing correspondence? Or what? Sitting close enough to read the flow of his notes one day, I found out what was going on. Bob was writing material for the principles of economics text he was doing with Bob Ekelund! There in all the chatter about budget battles, the next hearings on the Hill, controversies involving agency enforcement actions, and preparation of major arguments before the commission, Tollison was focused on a discussion of property rights and the Coase Theorem. But having said this, I must hasten to point out that, unlike ordinary human beings, Bob could do this while simultaneously keeping a partial ear open to the meeting conversation. Indeed, there would be times, when he would stop writing, put down his pen, look around the table, and offer an on-target comment about the subject being discussed. In fact, he would often provide a concise summary of what he had been hearing along with a closing thought that would gracefully bring a conclusion to the topic so that rest of us could move to the next agenda item. As mentioned earlier, Bob had a doublebarreled brain. One barrel was focused on writing a principles book; the other on what was going on at the FTC. 
Another FTC memory illustrates a special Tollison trait. In debate or presentation, he would make his points quietly and often persuasively..., most of the time. But this was not always to be the case when presenting before the seated commissioners. They were not always ready to be persuaded. In fact, some were well-armed to resist being persuaded, especially by an economist. A favorite example of this concerns a presentation Bob made regarding possible mergers of major producers of soft drinks. During the 1980s, major mergers were attempted by Coca-Cola and Dr. Pepper and by Pepsico and 7-Up. When these and other horizontal mergers surfaced at the Commission, there were always questions about loss of competition and the potential for merger-induced monopolization of markets. Availability of substitute goods in affected markets was always a critical consideration when the FTC's Bureau of Economics performed an analysis of a pending horizontal merger.

In briefing the Commission on the competitiveness of the soft drink industry and how competition would be affected if mergers were to occur between one of the industry giants and a smaller firm, Bob pointed out that there were many cola substitutes available to consumer,. To put it another way, the demand curve for any one brand of soft drinks was relatively flat; not much monopoly power was available to producers in those markets. After quietly making this point to the assembled commissioners, Bob concluded his presentation and asked if there were any questions. "Can you give us an example of substitutes for Coca-Cola," one of the commissioners asked. "Yes," Bob responded quietly, "There are other cola products, fruit-flavored drinks, non-colas, and even drinking water, anything that can quench a consumer's thirst." There was a brief moment of silence. Remember, this was in the early 1980s. "Do you mean to say that consumers would pay for drinking water"? the commissioner asked in a tone of disbelief. "Just plain water in a bottle or something"? "Yes," Tollison, responded, "That's just what I mean." There were disdainful chuckles heard all around table as several commissioners smiled at such a strange idea. Chairman Miller, who was not laughing, moved to the next item on the agenda. Bob maintained his easy-going demeanor and thanked the commissioners for their kind attention. Bottled water was on its way to becoming a formidable cola competitor, but no one at the table, other than Bob, seemed to recognize what might be coming.

I was privileged to be a colleague with Bob Tollison, briefly at the FTC, and then for a much longer period at Clemson. He was always an inspiration to me. His scholarly work was boundless. He loved students. He relished opportunities to be engaged in serious discussions with colleagues. He loved having fun. And he loved to write.

Just before the start of Clemson's 2016 fall semester, I learned that Bob would not be teaching his scheduled classes. When I became aware of Bob's semester leave, I decided that I should write a letter to him, reminding him of that 1969 Southern Economic Association meeting and thanking him for his guidance and inspiration over the intervening decades. I did that. My letter was dated September 11, 2016. On September 22, I received a short hand-written note from Bob, thanking me for my letter. Bob Tollison died on October 24. He was an intellectual giant and a good man.

\section{References}

Crain, N. V., \& Crain, W. M. (2010). Determinants of publication productivity: An empirical analysis. Public Choice, 142, 265-277.

Gladwell, M. (2008). Outliers. New York, NY: Little, Brown and Company. 